Bull. Chem. Soc. Ethiop. 2014, 28(1), 17-28.

Printed in Ethiopia

ISSN 1011-3924

DOI: http://dx.doi.org/10.4314/bcse.v28i1.3

(c) 2014 Chemical Society of Ethiopia

\title{
GEOCHEMICAL ASSESSMENT OF SEDIMENT IN CAPE TOWN HARBOUR, SOUTH AFRICA
}

\author{
Hussein K. Okoro ${ }^{1,2^{*}}$, Olalekan S. Fatoki ${ }^{1}$, Folahan A. Adekola ${ }^{2}$, Bhekumusa J. Ximba ${ }^{1}$ and \\ Reinette G. Snyman ${ }^{3}$ \\ ${ }^{1}$ Environmental-Analytical Research Laboratory, Department of Chemistry, Faculty of Applied \\ Science, Cape Peninsula University of Technology, P. O. Box 1906, Cape Town, 7535 South \\ Africa \\ ${ }^{2}$ Environmental-Analytical Research Laboratory, Department of Industrial Chemistry, Faculty of \\ Physical Science, University of Ilorin, P.M.B.1515, Ilorin, Nigeria \\ ${ }^{3}$ Department of Biodiversity and Conservation Management, Faculty of Applied Sciences, Cape \\ Peninsula University of Technology, P. O. Box 652 Cape Town 8000, South Africa
}

(Received January 17, 2013; revised November 4, 2013)

\begin{abstract}
Geochemical assessment of marine sediments collected from Cape Town harbour was carried out using inductively coupled plasma-mass spectrometry, Fourier-Transform-infrared and X-ray diffractrometry techniques. The clay mineral phase consists of biotites, kaolinites and halites. The ranges of concentrations $(\mathrm{mg} / \mathrm{kg})$ of trace metals were: $\mathrm{Cd}(1.69 \pm 0.075-0.080 \pm 0.002), \mathrm{Si}(0.37 \pm 0.11-0.023 \pm 0.012), \mathrm{Fe}(30.01 \pm 2.04-$ $2.23 \pm 0.12), \mathrm{Cu}(1462 \pm 39-1.51 \pm 0.11), \mathrm{Al}(19.92 \pm 2.24-1.25 \pm 0.13), \mathrm{Sn}(63.98 \pm 4.97-1.15 \pm 0.38), \mathrm{Pb}(252 \pm 29$ $-8.73 \pm 1.06), \mathrm{Hg}(1.002 \pm 0.168-0.049 \pm 0.005)$ and $\mathrm{Zn}(1.26 \pm 0.07-0.022 \pm 0.004) \mathrm{mg} \mathrm{kg}^{-1}$. The enrichment factors of $\mathrm{Sn}, \mathrm{Pb}, \mathrm{Zn}, \mathrm{Fe}, \mathrm{Cd}, \mathrm{Al}$ and $\mathrm{Hg}$ revealed anthropogenic inputs of these metals into the marine environment. The enrichment factor of $\mathrm{Cu}$ was less than 1 and this suggests that its presence was largely due to natural changes. The results are indications of the contributions of trace metals contained in the runoffs from the domestic and urban drains, as well as the inflow storm water. Ship repair activities appeared to constitute a major factor responsible for the higher metal contamination in the dockyard areas. The geomineral analyses revealed the presence of quartz, pyrite, and calcite and carrolite minerals as the main constituents of the marine sediments.
\end{abstract}

KEY WORDS: Marine sediment, Geochemistry, X-Ray diffractometry, Dockyard, Heavy metals

\section{INTRODUCTION}

The mineral composition of coastal and marine sediments is of broad interest because of its relevance to assessment of environmental change. A number of studies have been carried out on the mineral distribution of the coastal environment and it has been observed that the mineral distribution in the marine environment morphology is an indication of the sediment source and sea level [1-2].

Generally, contaminants in sediments have been known to have direct adverse effects if they exceed certain concentrations in an organism [3]. Sediments are the major carriers of trace elements in the hydrosphere. Sediments and water have been used globally to assess the pollution levels in aquatic ecosystems [4-6]. Similar studies have been carried out in South Africa [7-12]. Sediment particles are made up of materials derived from rock, soil and anthropogenic sources. Silicate and aluminosilicate represent the basic structural units of inorganic sediments $[2,8,13-15]$. Organic matter in sediments is a product of the synthesis of biomolecules by marine organisms and from terrigerous sources. They are mostly introduced into water bodies and marine inflows [16]. Thus the main components of minerals include clay, quartz, feldspar, silicate minerals, gibbsite and calcium carbonate. Sediments can be classified according to their source, particle composition and size, percentage of organic matter, sorption

*Corresponding author. E-mail: okoroowo@yahoo.com 
capacity, porosity, and particle size distribution. All these properties determine the concentrations of contaminants in them.

Various techniques, such as thin section, differential thermal, X-ray diffraction, Mossbauer spectroscopy, magnetic studies, ultraviolet absorption and infrared spectroscopy have been used to carry out mineral analysis of sediment samples [2, 17-20]. Infrared spectroscopy has been reported as the best technique for mineral analysis because it is rapid, non-destructive and cost effective. A good number of studies conducted on geochemical characterization of sediments using Fourier transform infrared (FT- IR) technique are well documented in the literature [2, 1720].

In the present study, geochemical investigation of sediments samples from Cape Town harbour was undertaken using FT-IR and X-ray diffraction (XRD) techniques. The FT-IR was used for the identification of various chemical groups, including functional group present in the mineral constituents of the sediments while XRD technique was used to identify the mineral phases present in the sediment samples.

\section{EXPERIMENTAL}

\section{Study area}

Cape Town harbour is situated in Cape Town, South Africa $\left(33^{\circ} 54\right.$ 'S and $\left.18^{\circ} 26^{\prime} \mathrm{E}\right)$. The port has developed greatly over the centuries and currently consists of several main docks. The Ben Schoeman dock is the largest outer-dock of the port, where container terminals are positioned. The sediment samples collected at this site are very muddy. The Duncan dock is the smallest and the oldest inner dock, containing the multipurpose and fruit terminals as well as dry dock, repair quay and tanker basin. Both the water and sediment samples at this site are very muddy and oily. The Victoria and Alfred basin used to be the main pier of the original Cape Town harbour, but now houses the Victoria and Alfred waterfront. However, this basin is still used by smaller commercial vessels such as fishing and pleasure boats (smaller passenger cruise ships). The Synchrolift dry dock is where the ships are lifted up for repair. Sampling points on Cape Town harbour is represented in Figure 1.

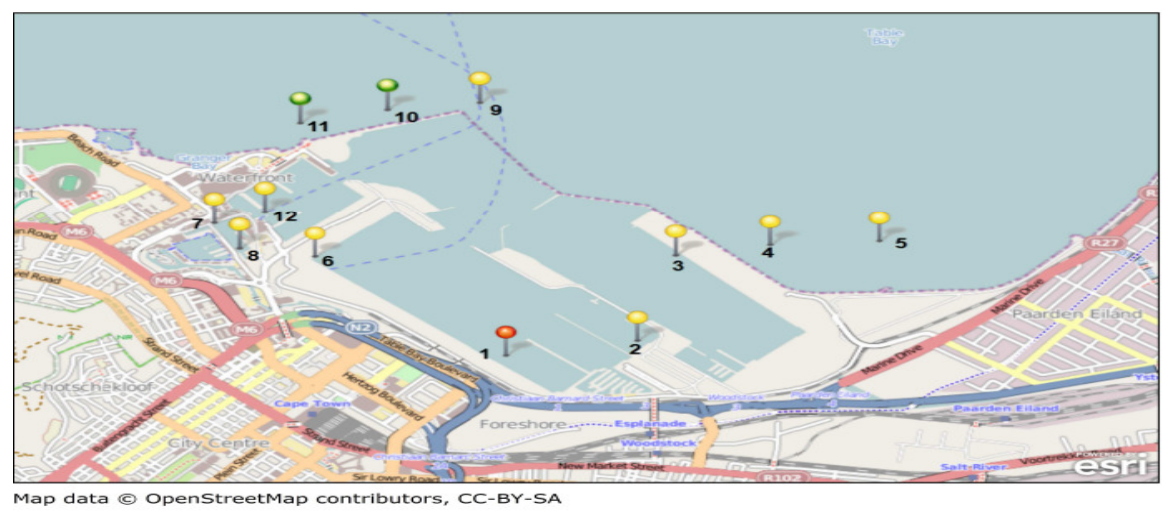

Figure 1. Map indicating sampling points in the Cape Town. 
Sample collection and preparation

Sample collection sites are shown in Figure 1. A boat from CSIR was used to collect samples in triplicate at each site. All samples were collected in September 2010. A Garmin GPS was used to locate the sampling points. Samples were collected during low tide except for samples 4 and 5 which were collected at high tide, because the weather changed suddenly on getting to location 4 and 5. Sample sites 1 to 9 were collected inside the harbour, while control samples 10 and 11 were collected outside the harbour at distances of $500 \mathrm{~m}$ and $1000 \mathrm{~m}$ from the harbour, respectively. The distances between control site $\mathrm{A}$ and $\mathrm{B}$, site 7 and 8 , site 6 and 9 , site 3 and 4 , site 4 and 5 are $513 \mathrm{~m}, 500 \mathrm{~m}, 265 \mathrm{~m}, 1400 \mathrm{~m}, 501 \mathrm{~m}$ and $572 \mathrm{~m}$, respectively. The overall distance covered during sampling was $16.4 \mathrm{~km}$. The coordinates of all the sampling points and the depths of sampling are presented in Table 1. The collected samples in plastic bags were covered with ice in a cooler box. The samples were dried for a week at room temperature. The dried sediments were ground using mortar and pestle, sieved with a $500 \mu \mathrm{m}$ sieve, homogenised and stored at $4{ }^{\circ} \mathrm{C}$ prior to total metal and geochemical examination.

Table 1. Sampling sites coordinates and sampling depths.

\begin{tabular}{|l|l|l|l|}
\hline Locations & Coordinates & Sampling depth & Sampling points \\
\hline 10 (Control A) & S33 53.862 E18 25.809 & $3 \mathrm{~m}$ & Point 10 \\
\hline 11 (Control B) & S33 53.926 E18 25.496 & $6 \mathrm{~m}$ & Point 11 \\
\hline 1 & S33 55.053 E18 26.236 & $14 \mathrm{~m}$ & Duncan Dock \\
\hline 2 & S33 54.982 E18 26.707 & $12 \mathrm{~m}$ & Duncan Dock \\
\hline 3 & S33 54.571 E18 26.842 & $14 \mathrm{~m}$ & Ben Schoeman Dock \\
\hline 4 & S33 54.518 E18 27.184 & & Inside sea 500 m away from point 3 \\
\hline 5 & S33 54.502 E18 27.566 & $15 \mathrm{~m}$ & Inside sea 500 m away from point 4 \\
\hline 6 & S33 54.574 E18 25.550 & $10 \mathrm{~m}$ & Duncan Dock \\
\hline 7 & S33 54.411 E18 25.190 & $12 \mathrm{~m}$ & Robinson DRY Dock \\
\hline 8 & S33 54.535 E18 25.279 & $14 \mathrm{~m}$ & Synchrolift \\
\hline
\end{tabular}

\section{Reagents}

Deionised water (18.2 $\mathrm{M} \Omega \mathrm{cm}$ from Millipore Bedford, MA USA) was used for all sample preparations. All reagents used were of analytical grade: acetone, potassium bromide powder (KBr) (Merck, South Africa). The sediment reference materials, BCR-277R for trace element and BCR-462 for butyltins were supplied by the European Community Bureau of Reference, IRMM, Belgium and Industrial Analytical, South Africa, respectively.

\section{Cleaning and pre-treatment of glassware}

All glassware were washed with a detergent, rinsed with deionised water, soaked overnight in $0.1 \mathrm{M} \mathrm{HNO}_{3}$ and thoroughly rinsed with deionised water. Mortar and pestle were oven dried for $24 \mathrm{~h}$ before use, $\mathrm{KBr}$ powder was baked in the oven for $6 \mathrm{~h}$ and stored in the dessicator.

\section{Instrumentation}

An Agilent 7700 Inductive Coupled Plasma-Mass Spectrometry (ICP-MS) was used for the determination of heavy metals. A centrifuge (BHG, Rotor Unit II) Nr. 7686 V220 A. 0.7 J 487 was used to obtain supernatant extracts at $4000 \mathrm{rpm}$ for $20 \mathrm{~min}$. A Milestone GmbH MLS 1200 Mega microwave digestor was used for sample dissolution in aqua regia. Infrared data were obtained using an FT-IR instrument. FT-IR (Spectrum one Spectrophotometer, Perkin 
Elmer, USA) was used for the analysis. X-Ray Powder Diffraction (XRPD) instrument used was a Phillip PANnalytical PW 3830/40 X-ray generator with a PW 3710 MPD control. X-ray diffraction (XRD) system which uses the Xpert software programme for data collection and mineral identification was used. The instrument was operated at $40 \mathrm{kV}$ and $25 \mathrm{~mA}$ and sufficient water pressure was maintained at 400-600 $\mathrm{kPa}$. The instrument was coupled with curved $\mathrm{Cu}$-filtered $\mathrm{Cu}-\mathrm{K}_{\alpha}$ radiation with slow scan speed of $0.040^{\circ} / \mathrm{s}$.

\section{Sample preparation for total metal analysis}

Sample dissolution was done using a microwave-assisted acid digestion procedure [21]. Three replicates of $1 \mathrm{~g}$ of each sample were digested with a aqua regia $\left(7.5 \mathrm{~mL} \mathrm{HCl}: 2.5 \mathrm{~mL} \mathrm{HNO}_{3}\right)$. Samples were heated in the microwave unit. The digested samples were cooled, filtered, and the filtrate was diluted to the mark in a $100 \mathrm{~mL}$ volumetric flask. The samples were then analysed using the ICP-MS instrument.

\section{Sample preparation and infrared analysis}

Each sample of 20-mg was mixed with $400 \mathrm{mg}$ of spectroscopic $\mathrm{KBr}$ in the ratio 1:20 using a mortar and pestle. Before mixing, a required amount of $\mathrm{KBr}$ powder was dried at $120{ }^{\circ} \mathrm{C}$ for $6 \mathrm{~h}$ in an oven in order to prevent the broad $\mathrm{OH}$ spectral peak of water from interfering with hydroxyls associated with any of the minerals. The mortar and pestle were also dried in an oven for $24 \mathrm{~h}$ before use. Each sediment sample was weighed in a microbalance and placed in a clean mortar along with the proper amount of dry $\mathrm{KBr}$ to prepare a sample pellet. The size of each pellet prepared was $1 \mathrm{~mm}$ in thickness and $13 \mathrm{~mm}$ in diameter. The prepared pellet was preserved in a moisture-free glass container before it was placed in a suitable sample holder and introduced in the infrared beam for analysis. The infrared spectra of the samples were measured at room temperature. For quality control, the instrument was calibrated for its accuracy with the spectrum of a standard $\mathrm{KBr}$ powder. Each time before the spectrum of sample is obtain, the spectrum of $\mathrm{KBr}$ powder was measured and checked for its accuracy. All spectra of samples were recorded in the range of 450-4000 $\mathrm{cm}^{-1}$. The time duration for each scan was one minute at $4.00 \mathrm{~cm}^{-1}$ resolution. The threshold value was $5.80 \% \mathrm{~T}$ while the normalization factor from the quantitative prediction was 1.00 .

\section{Sample preparation and XRPD analysis}

The XRPD instrument was used to determine the solid/mineral phases of the sediments. $1 \mathrm{~g}( \pm$ $0.0001 \mathrm{~g}$ ) of the surface sediment sample was weighed. This sample was ground to powder using mortar and pestle. Each powdered sample was sieved through a $40 \mu \mathrm{m}$ mesh in order to remove sand particles, and the prepared sample was ready for XRD analysis. The XRPD measurements were performed at room temperature using cooled dry nitrogen $\left(\mathrm{N}_{2}\right.$ gas). The PXRD profiles were acquired using a step width of 0.02 deg with a counting time of $0.040^{\circ} / \mathrm{s}$ step. The total time taken to analyse each sample was $32 \mathrm{~min}$ and $30 \mathrm{~s}$ and the total number of steps for each run was 3900 . The Xpert graphics collector software was used for data collection and analysis. For most identification a continuous scan from 2 to $80^{\circ} 2 \Theta$ with a step size of $0.02^{\circ} 2 \Theta$ was used. Ethanol was used to clean the sample holder after use to avoid any contamination. 


\section{RESULTS AND DISCUSSION}

The concentration levels of nine elements determined by ICP-MS are shown in Table 2. Sn was principally present across all locations. The highest value recorded for Sn was $63.98 \pm 4.97$ $\mathrm{mg} / \mathrm{kg}$ for location 8 and a minimum concentration of $1.15 \pm 0.38 \mathrm{mg} / \mathrm{kg}$ for location 9 . The high values recorded for $\mathrm{Sn}$ at this location was certainly due to reparation and painting of ships. Tributyltin (TBT) is the major antifouling agent added in ship paint. Organotin compounds have adverse effect on the aquatic life in the sea [22]. Therefore adequate proper control must be undertaken to ban the use of this antifouling agent (organotins) in ship painting. The distribution of $\mathrm{Pb}$ across all locations follows the same pattern as $\mathrm{Sn}$. The highest concentration recorded was $251.7 \pm 29.02 \mathrm{mg} / \mathrm{kg}$ at location 8 while the lowest concentration was $8.73 \pm 1.07 \mathrm{mg} / \mathrm{kg}$ at location 9. The nature of industrial activities such as explosive manufacturing industry near the harbour could explain the presence of high concentration of $\mathrm{Pb}$ in the sediment of Cape Town harbour. $\mathrm{Cu}$ exhibited the highest mean concentration at location 2 while it recorded lowest mean concentration at location 7. Cu had the highest concentration followed by $\mathrm{Pb}$ across all the locations. Industrial activities taking place at location 2 could be responsible for this observation.

The concentration of $\mathrm{Zn}$ was generally lower than that of $\mathrm{Cu}$ at all locations. The highest concentration was recorded at location 8 again while the lowest concentration was recorded at location at location 9. The highest concentration would most certainly be due to the intense industrial activities and this is anthropogenic in nature. The distribution of $\mathrm{Fe}$ in all the sediments varied across locations. Fe was principally present in form of iron oxide with the concentration ranging from $28.75 \pm 1.85 \mathrm{mg} / \mathrm{kg}$ for location 7 and $30.01 \pm 2.04 \mathrm{mg} / \mathrm{kg}$ for location 8 , respectively, the exceptionally high values of Fe at location 7 and 8 could be connected with the intensive industrial operations that were previously mentioned above. The lowest concentration for Fe was recorded at location 9 (entrance to harbour). This is because the area is sandy and therefore has naturally low iron content in the sediment.

$\mathrm{Cd}$ was generally present at lower concentration across all locations. The highest concentration of $\mathrm{Cd}$ was recorded at location 8 while the minimum concentration was recorded at location $9 . \mathrm{Hg}$ concentration was low across all levels. The concentration ranged between $1.00 \pm 0.17 \mathrm{mg} / \mathrm{kg}$ for location 8 and $0.049 \pm 0.005 \mathrm{mg} / \mathrm{kg}$ for location 4 . The high value recorded at location 8 could be as a result of run-off from motor scrap collection points. The concentration of $\mathrm{Al}$ varied across all locations. The highest values recorded were $19.92 \pm 2.24$ for location 6 and lower concentration of $1.25 \pm 0.13 \mathrm{mg} / \mathrm{kg}$ for location 9 . This follows the same pattern with $\mathrm{Zn}$ and $\mathrm{Fe}$. The high concentration values recorded for $\mathrm{Al}$ in location 8 could be as a result of routine painting and reparation of ships being undertaken at this location. There was variation in the concentration of silica between the sites sampled. The concentration of Si was generally low. The highest concentration recorded for $\mathrm{Si}$ was $0.37 \pm 0.11 \mathrm{mg} / \mathrm{kg}$ for location 9 (entrance to harbour), followed by $0.35 \mathrm{mg} / \mathrm{kg}$ for location 8 (Synchrolift), and the lowest concentration of $0.023 \pm 0.012 \mathrm{mg} / \mathrm{kg}$ was in location 1 (Duncan dock). The high silicon concentrations recorded in location 8 and 9 could be as a result of intensive reparation and painting activities at location 8 (Synchrolift) as well as from sand, diatom frustules and runoffs at location 9.

Enrichment factor (EF) is widely employed to identify the anthropogenic source of metallic element [23]. The value of enrichment coefficient is, however, used to evaluate the degree of enrichment of some chemical elements when they are compared with their natural sources [24]. The EF may be due to either natural or anthropogenic causes. The EF has been calculated using the expression below. 


$$
\mathrm{EF}=\frac{(\mathrm{X} / \mathrm{RE})_{\text {Sample }}}{(\mathrm{X} / \mathrm{RE})_{\text {Control }}}
$$

where $\mathrm{EF}$ represent $=$ enrichment factor, $\mathrm{RE}=$ reference element, $\mathrm{X}_{\text {sample }}=$ measured element, $(\mathrm{RE})_{\text {control }}=$ control value for reference element, $(\mathrm{X})_{\text {Control }}=$ control value for measured element.

Table 2. Results of total metal analysis in $\mathrm{mg} / \mathrm{kg}$ in sediment sample from Cape Town harbour.

\begin{tabular}{|c|c|c|c|c|c|c|c|c|c|}
\hline Location & $\mathrm{Sn}$ & $\mathrm{Pb}$ & $\mathrm{Cu}$ & $\mathrm{Zn}$ & $\mathrm{Fe}$ & $\mathrm{Cd}$ & $\mathrm{Al}$ & $\mathrm{Si}$ & $\mathrm{Hg}$ \\
\hline 1 & $4.97 \pm 1.04$ & $45.3 \pm 7.6$ & $75.7 \pm 11.1$ & $0.10 \pm 0.01$ & $13.1 \pm 2.6$ & $0.34 \pm 0.05$ & $18.02 \pm 2.31$ & $0.02 \pm 0.01$ & $0.16 \pm 0.05$ \\
\hline 2 & $7.7 \pm 2.8$ & $65.8 \pm 24.2$ & $1462 \pm 39$ & $0.45 \pm 0.31$ & $13.3 \pm 3.1$ & $0.7 \pm 0.2$ & $13.7 \pm 4.3$ & $0.04 \pm 0.01$ & $0.17 \pm 0.06$ \\
\hline 3 & $2.05 \pm 0.21$ & $16.6 \pm 2.7$ & $21.9 \pm 2.9$ & $0.06 \pm 0.00$ & $13.5 \pm 0.8$ & $0.16 \pm 0.03$ & $14.8 \pm 1.6$ & $0.09 \pm 0.01$ & $0.08 \pm 0.01$ \\
\hline 4 & $1.18 \pm 0.30$ & $9.22 \pm 0.29$ & $8.32 \pm 0.41$ & $0.030 \pm 0.003$ & $4.7 \pm 0.22$ & $0.14 \pm 0.02$ & $3.8 \pm 0.4$ & $0.13 \pm 0.02$ & $0.05 \pm 0.01$ \\
\hline 5 & $1.15 \pm 0.15$ & $10.31 \pm 0.28$ & $10.47 \pm 3.8$ & $0.03 \pm 0.00$ & $3.04 \pm 0.12$ & $0.22 \pm 0.01$ & $2.5 \pm 0.1$ & $0.3 \pm 0.1$ & $0.2 \pm 0.1$ \\
\hline 6 & $5.0 \pm 0.1$ & $44.4 \pm 0.9$ & $71.1 \pm 1.2$ & $0.1 \pm 0.2$ & $15.1 \pm 1.2$ & $0.40 \pm 0.04$ & $19.9 \pm 2.0$ & $0.09 \pm 0.02$ & $0.12 \pm 0.09$ \\
\hline 7 & $34.3 \pm 2.7$ & $158 \pm 12$ & $1.5 \pm 0.1$ & $0.85 \pm 0.04$ & $28.8 \pm 1.90$ & $0.70 \pm 0.05$ & $17.63 \pm 0.97$ & $0.02 \pm 0.003$ & $0.65 \pm 0.10$ \\
\hline 8 & $63.9 \pm 4.9$ & $251 \pm 29$ & $1.9 \pm 0.3$ & $1.3 \pm 0.1$ & $30.0 \pm 2.0$ & $1.7 \pm 0.1$ & $17.3 \pm 0.7$ & $0.4 \pm 0.3$ & $1.0 \pm 0.2$ \\
\hline 9 & $1.1 \pm 0.4$ & $8.7 \pm 1.1$ & $6.1 \pm 0.6$ & $0.02 \pm 0.00$ & $2.2 \pm 0.12$ & $0.08 \pm 0.00$ & $1.2 \pm 0.1$ & $0.4 \pm 0.1$ & $0.06 \pm 0.01$ \\
\hline 10 & $10.64 \pm 4.92$ & $30.0 \pm 3.9$ & $27.7 \pm 1.6$ & $0.10 \pm 0.00$ & $12.03 \pm 0.19$ & $0.09 \pm 0.01$ & $2.9 \pm 0.3$ & $0.09 \pm 0.03$ & $0.07 \pm 0.04$ \\
\hline 11 & $3.67 \pm 1.36$ & $13.7 \pm 3.06$ & $13.5 \pm 1.7$ & $0.03 \pm 0.00$ & $4.4 \pm 0.1$ & $0.14 \pm 0.01$ & $2.32 \pm 0.18$ & $0.10 \pm 0.02$ & $0.06 \pm 0.01$ \\
\hline
\end{tabular}

In this study $\mathrm{Si}$ was chosen as the reference element due to its steady chemical characteristics. The sources of these heavy metals have been confirmed by calculating the EF for all the metals using $\mathrm{Si}$ as a reference element and also location 11 as control site due to the reduced level of metal contamination recorded at this location. The EF for all the metals is represented in Table 3. EF values of between 0.5 and 2 are considered to be indicative of natural factors while values greater than 2 are attributed to anthropogenic causes [17]. The EF values of locations 4 and 5 (inside sea), 10 (remote location) and 9 (entrance to harbour) ranged from 1.00 to 3.26 , and this is due to both anthropogenic and natural contribution.

The EF of all the metals in location 1 and 2 (Duncan Dock) are generally greater than those in location 3 (Ben Schoeman Dock). The EF values for location 3 is between 0.65 to 3.65 for all the metals except $\mathrm{Al}$ which is higher than 3 (7.45) (Table 3), the enrichment of $\mathrm{Al}$ at this location is due to anthropogenic effects while others were due to natural changes. At locations $6, \mathrm{~Pb}, \mathrm{Cu}, \mathrm{Zn}, \mathrm{Fe}, \mathrm{Cd}, \mathrm{Al}$ are highly enriched while the $\mathrm{EF}$ values for $\mathrm{Hg}$ and $\mathrm{Sn}$ were below 3 . For locations 7 and 8 (Robinson drydock and Synchrolift), the EF values recorded for $\mathrm{Sn}, \mathrm{Pb}$, $\mathrm{Zn}, \mathrm{Fe}, \mathrm{Cd}, \mathrm{Al}$ and $\mathrm{Hg}$ were much higher. Metal contamination in these two locations is due to anthropogenic activities such as ship repairs, runoff from domestic, industrial and storm water into the harbour. The EF values for $\mathrm{Cu}$ in these locations were below 1, and this signifies that its presence is due to natural changes. Higher level of EF recorded for Iron across the locations was an indication of intensive industrial operations: The highest EF for copper was observed in location 2 (Table 3), which confirms the predominant presence of calcite in this location. Industrial activities taking place at this location could also be responsible for these observations.

FTIR was used to investigate the mineral composition of the harbour sediments. The absorption frequencies of the peaks in the spectra of each location in wave number units $\left(\mathrm{cm}^{-1}\right)$ are recorded in Table 4 and the IR spectra of the sediment samples is shown in Figure 2. The following minerals were confirmed in the sediment samples across all locations when their observed frequencies were compared with that of literature: quartz, calcite, pyrites, and carrolite (Table 5). The following minerals were identified from the analysis of two certified reference materials: quartz, feldspar, kaolinite and calcite (Table 5). The IR spectra for the certified reference materials for trace element and organotin compounds are shown in Figure $2 \mathrm{~b}, \mathrm{c}$. The presence of $\mathrm{Fe}$ was confirmed across all locations. The literature values of the absorption frequencies of most minerals are summarised in Table 5.

Bull. Chem. Soc. Ethiop. 2014, 28(1) 
Table 3. Table of enrichment factors.

\begin{tabular}{|c|c|c|c|c|c|c|c|c|c|}
\hline Locations & $\mathrm{Sn}$ & $\mathrm{Pb}$ & $\mathrm{Cu}$ & $\mathrm{Zn}$ & $\mathrm{Fe}$ & $\mathrm{Cd}$ & $\mathrm{Al}$ & $\mathrm{Si}$ & $\mathrm{Hg}$ \\
\hline 1 & 6.34 & 15.89 & 26.74 & 13.67 & 14.41 & 11.78 & 37.15 & 1.00 & 13.73 \\
\hline 2 & 6.53 & 15.17 & 339.55 & 40.07 & 0.33 & 16.03 & 18.56 & 1.00 & 9.64 \\
\hline 3 & 0.65 & 1.42 & 1.90 & 1.91 & 3.61 & 1.39 & 7.45 & 1.00 & 1.68 \\
\hline 4 & 0.27 & 0.57 & 0.52 & 0.74 & 0.91 & 0.83 & 1.37 & 1.00 & 0.73 \\
\hline 5 & 0.14 & 0.33 & 0.34 & 0.36 & 0.31 & 0.70 & 0.48 & 1.00 & 1.15 \\
\hline 6 & 1.59 & 3.81 & 6.15 & 3.81 & 4.05 & 3.07 & 10.04 & 1.00 & 2.54 \\
\hline 7 & 42.55 & 53.23 & 0.51 & 111.90 & 30.19 & 23.12 & 34.80 & 1.00 & 53.10. \\
\hline 8 & 5.44 & 5.78 & 0.04 & 11.29 & 2.15 & 3.84 & 2.33 & 1.00 & 53.60 \\
\hline 9 & 0.09 & 0.19 & 0.14 & 0.19 & 0.15 & 0.17 & 0.16 & 1.00 & 0.30 \\
\hline 10 & 3.26 & 2.50 & 2.32 & 3.31 & 3.12 & 0.71 & 1.46 & 1.00 & 1.40 \\
\hline
\end{tabular}

Table 4. IR frequencies of Cape Town harbour sediments and their assignments.

\begin{tabular}{|c|c|}
\hline Locations & Observed IR absorption frequencies $\left(\mathrm{cm}^{-1}\right)$ \\
\hline 1 (Duncan Dock) & $\begin{array}{l}458.23,502.12,685.92,828.58,1034.33,1336.10,1465.10,1640.61, \\
2928.57,3434.75,3697.80\end{array}$ \\
\hline 2 (Duncan Dock) & $\begin{array}{l}\text { 460.97, 532.30, 691.41, 823.09, 1333.36, 1455.77, 1599.46, 1766.81, } \\
\text { 2516.48, 2934.06, 3434.91 }\end{array}$ \\
\hline 3 (Ben Schoeman Dock) & $\begin{array}{l}496.63,688.67,823.09,1341.59,1452.07,1602.21,2521.97,3406.59 \text {, } \\
3619.89,3697.33\end{array}$ \\
\hline 4 (Inside Sea) & $\begin{array}{l}\text { 463.71, 617.34, 778.24, 823.09, 1308.67, 1466.24, 1585.75, 2510.98, } \\
\text { 2923.07, 3420.02 }\end{array}$ \\
\hline 5 (Inside Sea) & $\begin{array}{l}469.20,707.87,825.84,866.99,1253.80,1602.21,2516.48,3016.48 \text {, } \\
3427.05\end{array}$ \\
\hline 6 (Duncan Dock) & $\begin{array}{l}499.38,685.92,823.09,1330.61,1455.80,1585.75,2516.48,2934.06 \text {, } \\
3431.38\end{array}$ \\
\hline 7 (Robinson DRY Dock0 & $\begin{array}{l}535.04,685.92,825.84,908.14,1455.89,2516.48,2912.08,3420.81 \text {, } \\
3703.29\end{array}$ \\
\hline 8 (Synchrolift) & $\begin{array}{l}535.04,688.67,831.32,919.11,1325.13,1455.74,1583.00,1794.24, \\
2928.57,3434.35\end{array}$ \\
\hline 9 (Entrance to harbour) & $669.46,1190.70,1473.27,3445.05$ \\
\hline $10($ Control A) & $707.87,820.35,869.73,1465.04,1748.88$ \\
\hline 11 (Control B) & $589.91,820.35,2923.07,3450.54$ \\
\hline
\end{tabular}

All the mineral phases observed from the XRD data are summarised in Table 5. XRD data was used for qualitative mineralogical determination of marine sediments. The qualitative mineralogy of the marine sediment of Cape Town harbour were determined with the standard interpretation procedures of XRD. The minerals phases were explored from the XRD data. The diffractograms of all samples is the same. Quartz is the most common mineral in the geosphere, and it is normally found in most geological environments. Calcite and carrolite are also found in most of the sampled sites. Calcite is a carbonate mineral of calcium. Pyrites are present in locations 2, 6, 8 and 10. Carbonates are commonly found in marine sediments when the shells of dead planktonik life settle and accumulate on the sea floor [20]. Carrolite is a grey metallic sulphide mineral containing a rich mixture of $\mathrm{Cu}, \mathrm{Co}$, and $\mathrm{Ni}$. It is composed of approximately $40 \% \mathrm{Co}$ and $20 \% \mathrm{Cu}$. Fe, $\mathrm{Ni}$ and $\mathrm{S}$ are also found in this mineral. It has chemical formula $\mathrm{Cu}(\mathrm{Co}, \mathrm{Ni})_{2} \mathrm{~S}_{4}$, Carrolite is a rare mineral recently found in Africa. The presence of this mineral in these locations leads to high concentration levels of $\mathrm{Cu}$ and Fe observed in location 1, 2, 4, $5,6,7,8,9$ and 11. Kaolinite and feldspar were only confirmed in the BCR -277 certified reference material as shown in Table 6 . Two certified reference materials were also subjected to 
XRD investigation. The organotins did not produce any signal during XRD examination and this confirms the absence of mineral phase while the second reference material produced characteristic peaks. The representative XRD spectra are shown in Figure 3a-c.

Table 5. IR absorption frequencies $\mathrm{cm}^{-1}$ of quartz, pyrite ${ }^{\mathrm{a}}$, calcite ${ }^{\mathrm{b}}$, carolite ${ }^{\mathrm{c}}$, kaolinite ${ }^{\mathrm{d}}$ present in the sediment samples of Cape Town harbour and literature values of the absorption frequencies of most minerals.

\begin{tabular}{|c|c|c|c|c|c|c|c|c|c|c|c|c|c|c|c|}
\hline 1 & 2 & 3 & 4 & 5 & 6 & 7 & 8 & 9 & 10 & 11 & $\begin{array}{l}\text { BCR - } \\
277 R\end{array}$ & $\begin{array}{c}\text { BCR - } \\
462\end{array}$ & Mineral & Frequency & Ref. \\
\hline 458 & $\begin{array}{l}460.97, \\
691.41\end{array}$ & 689 & 778.24 & 825.84 & 685.92 & 825.84 & 688.67 & 669.46 & 820.35 & 820.35 & $\begin{array}{c}797.6 \\
{[26]}\end{array}$ & $\mathrm{NF}$ & Quartz & $\begin{array}{c}458,455 \\
798 \\
695\end{array}$ & $\begin{array}{c}{[25,26]} \\
{[27]}\end{array}$ \\
\hline $502^{\mathrm{a}}$ & $\begin{array}{l}532.30^{\mathrm{a}}, \\
691.41^{\mathrm{a}}\end{array}$ & $688.67^{\mathrm{a}}$ & $617.34^{\mathrm{a}}$ & & $685.92^{\mathrm{a}}$ & $535^{\mathrm{a}}, 685^{\mathrm{a}}$ & $535^{\mathrm{a}}, 685^{\mathrm{a}}$ & $669.5^{\mathrm{a}}$ & & $589^{a}$ & & $\mathrm{NF}$ & $\begin{array}{l}\text { Feld- } \\
\text { spar }\end{array}$ & $\begin{array}{l}540-533 \\
589-586 \\
644-640\end{array}$ & $\begin{array}{c}26,28] \\
{[26]} \\
{[25,26]}\end{array}$ \\
\hline $\begin{array}{c}685.92^{\mathrm{b}} \\
828.58^{\mathrm{b}} \\
3434^{\mathrm{c}}\end{array}$ & $\begin{array}{l}691.4^{\mathrm{b}} \\
823.1^{\mathrm{b}} \\
3434^{\mathrm{c}}\end{array}$ & $\begin{array}{l}688.7^{\mathrm{b}} \\
823.1^{\mathrm{b}}\end{array}$ & $\begin{array}{l}617.3^{\mathrm{b}} \\
778.2^{\mathrm{b}} \\
823.1^{\mathrm{b}} \\
3420^{\mathrm{c}}\end{array}$ & $\begin{array}{c}707^{\mathrm{b}} \\
825^{\mathrm{b}} \\
3427^{\mathrm{c}}\end{array}$ & $\begin{array}{l}685.9^{\mathrm{b}} \\
823.1^{\mathrm{b}} \\
3420^{\mathrm{c}}\end{array}$ & $\begin{array}{l}685^{b} \\
825^{b}\end{array}$ & $\begin{array}{c}688^{\mathrm{b}} \\
831^{\mathrm{b}} \\
3434^{\mathrm{c}}\end{array}$ & $\begin{array}{c}669^{\mathrm{b}} \\
3445^{\mathrm{c}}\end{array}$ & $\begin{array}{l}.707^{\mathrm{b}} \\
820^{\mathrm{b}} \\
870^{\mathrm{b}}\end{array}$ & $\begin{array}{c}820^{\mathrm{b}} \\
3450^{\mathrm{c}}\end{array}$ & $\begin{array}{l}797.62^{b} \\
3622^{d}\end{array}$ & $\mathrm{NF}$ & $\begin{array}{l}\text { Kao- } \\
\text { linite }\end{array}$ & $\begin{array}{c}908 \\
1035-1030 \\
3620 \\
3696-3695\end{array}$ & {$[29,30]$} \\
\hline & & & & & & & & & & & & & Calcite & $\begin{array}{c}1420-1380 \\
1300-1180 \\
1017-980 \\
900-600\end{array}$ & [31] \\
\hline & & & & & & & & & & & & & Pyrite & $500-700$ & [32] \\
\hline & & & & & & & & & & & & & $\begin{array}{l}\text { Carro- } \\
\text { lite }\end{array}$ & $\begin{array}{c}\text { Around } \\
3500\end{array}$ & [33] \\
\hline
\end{tabular}

Key: BCR-277R (for trace element), BCR-462 (for butyltins), N.F.: not found.

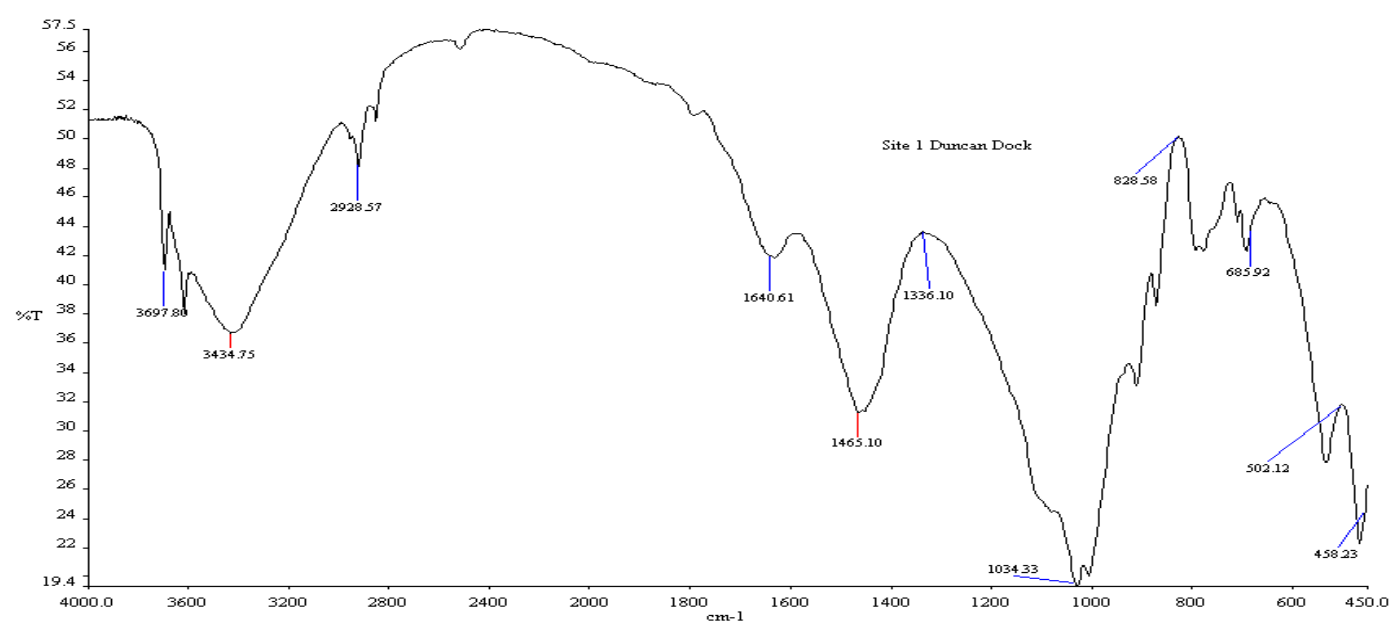

Figure 2a. A typical FTIR spectrum of a sediment sample collected from locations 1-9. 


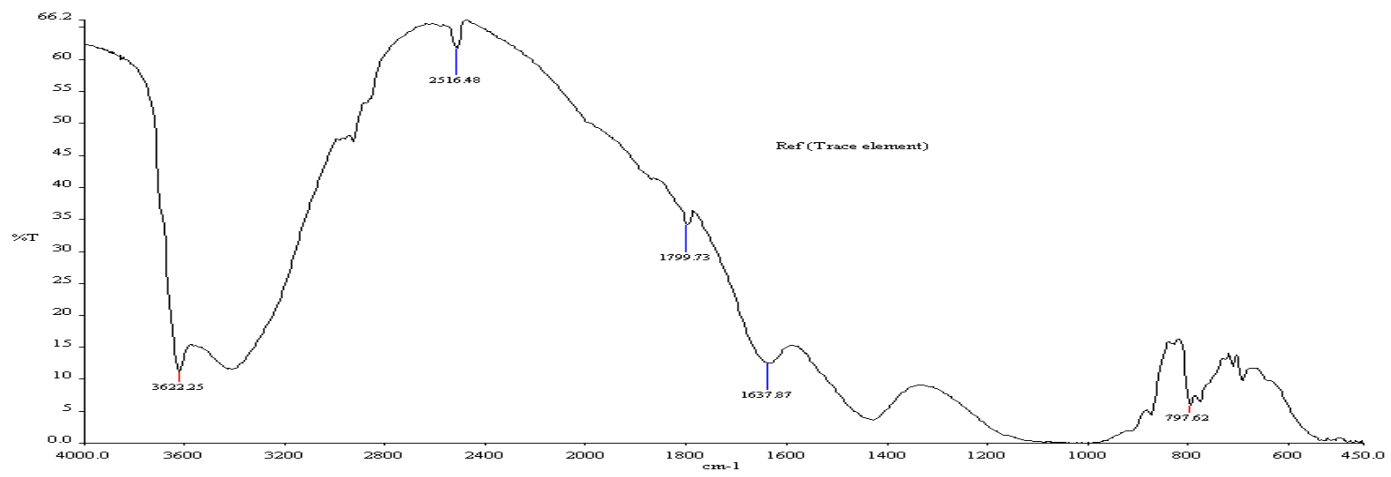

Figure $2 b$. Typical IR spectrum of certified reference sediment sample for trace elements.

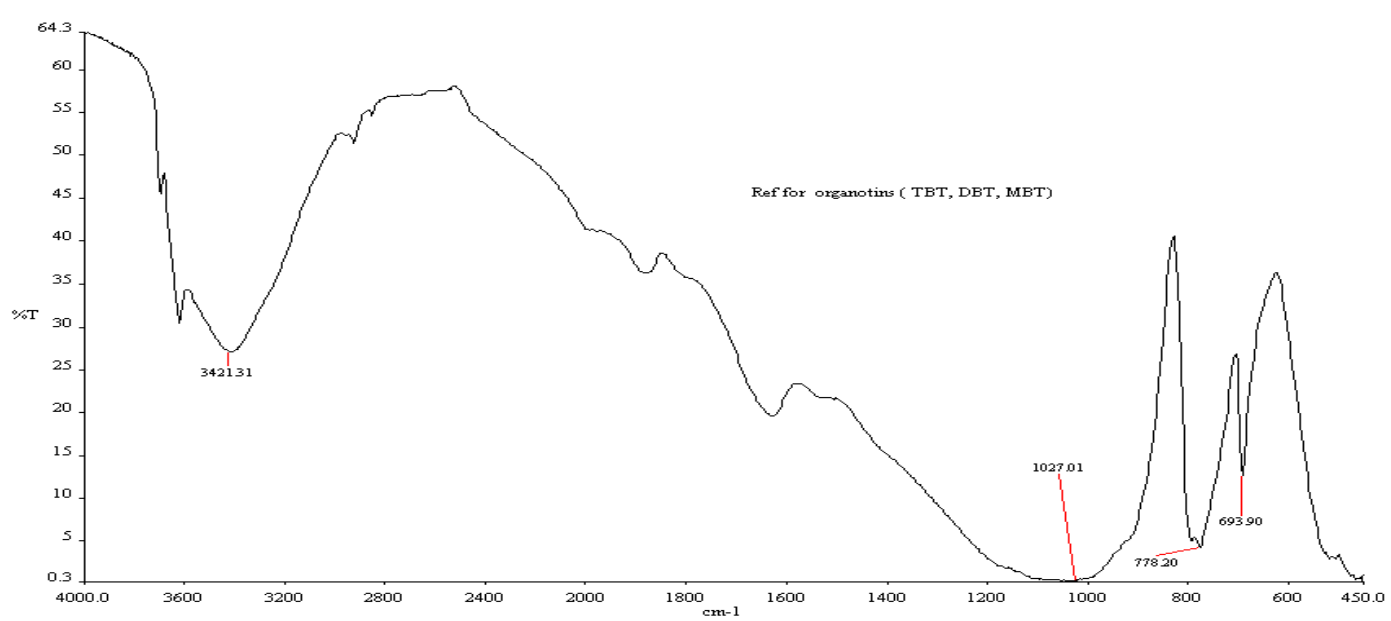

Figure 2c. Typical IR spectrum of certified reference sediment sample for organotin compounds.

Table 6. IR Frequencies of certified standard reference materials and their assignments.

\begin{tabular}{|l|l|}
\hline Sample & Observed IR absorption frequencies $\left(\mathrm{cm}^{-1}\right)$ \\
\hline BCR- 277R (for trace element ) & $797.62,1637.87,1799.73,2516.48,3622.25$ \\
\hline BCR -462 (for butyltins) & $693.90,778.20,1027.01,3421.31$ \\
\hline
\end{tabular}




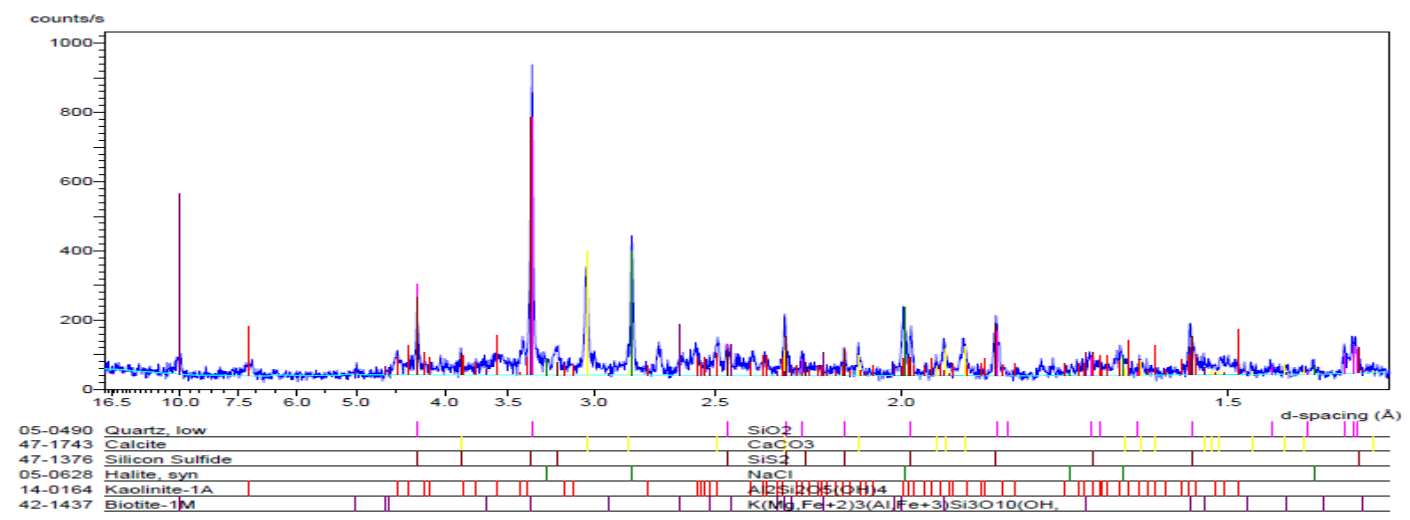

Figure 3a. A typical XRD diffractogram of a sample characterized from inner harbour (Snychrolift site) during summer season.

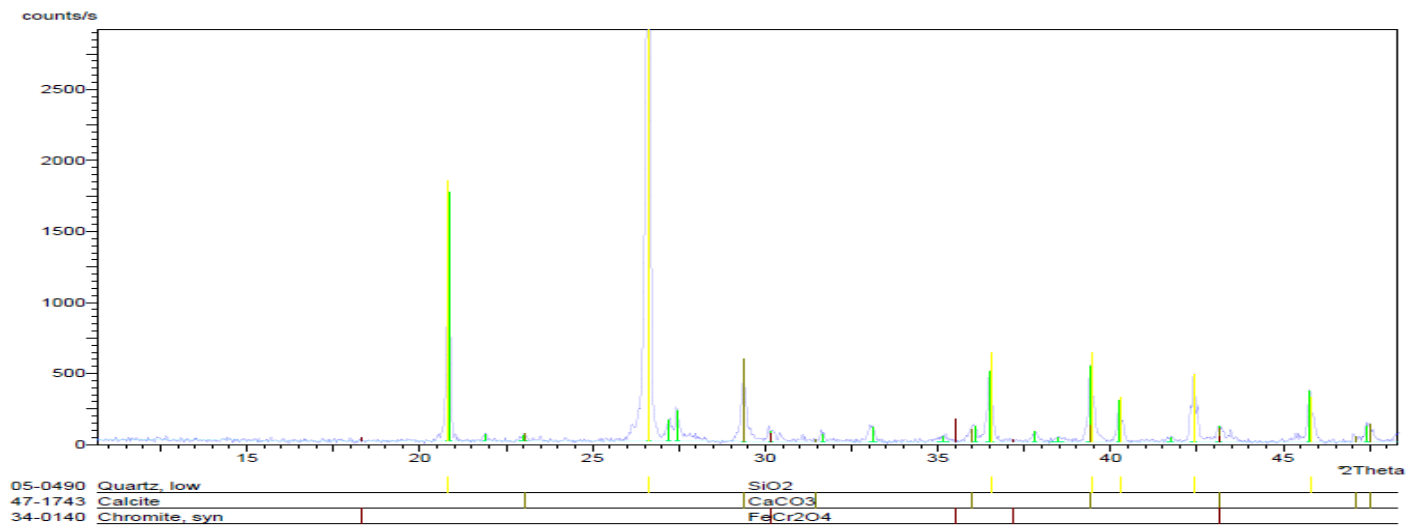

Figure 3b. A typical XRD diffractogram of a sample characterized from control site during winter season. 


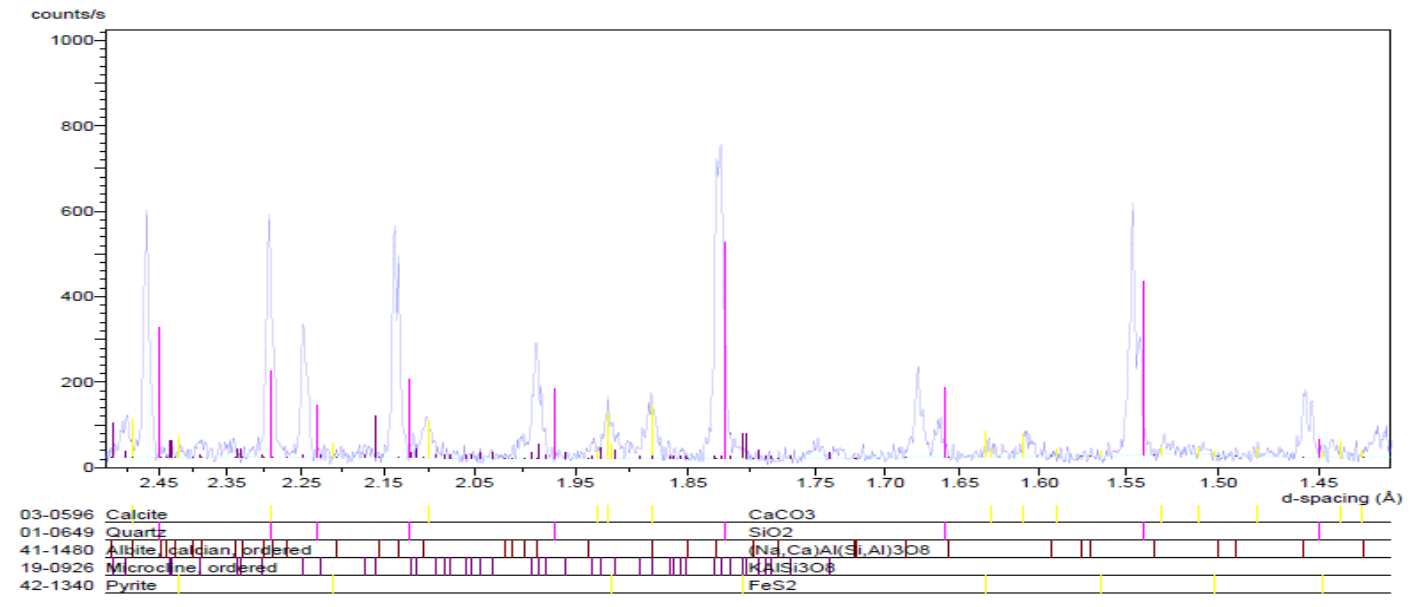

Figure 3c. A typical XRD diffractogram of a sample characterized from location 4 (inside sea) $500 \mathrm{~m}$ away from inner harbour during winter season.

\section{CONCLUSION}

The present study showed qualitative mineral identification of Cape Town harbour sediment using FTIR and XRD techniques. The study reveals the levels of contamination of Cape Town harbour. The results are indication of the contributions of heavy metals which carry runoff from the waste water treatment plant that discharges into the Diep River, as well as domestic, ocean current, and storm water inflow into the harbour. Ship reparation is a major suspected factor responsible for the higher metal contamination in dockyard areas of the harbour. The enrichment factor recorded for $\mathrm{Sn}, \mathrm{Pb}, \mathrm{Zn}, \mathrm{Fe}, \mathrm{Cd}, \mathrm{Al}$ and $\mathrm{Hg}$ in locations 7 and 8 were higher, and metal contamination in these locations is due to activities previously mentioned in this section. $\mathrm{Cu}$ concentration was low meaning that its presence was due to natural changes mentioned above. Since EF for Sn was high, a monitoring programme for Sn released from antifouling paints should be embarked on in the harbour. The ban on the use of these antifouling agents has been put under control in European countries and other developed countries, but in Africa the ban has not been effected. The FTIR and XRD analyses indicate the presence of quartz, pyrite, calcite and carrolite in the harbour sediments. The combination of the two techniques showed that they are useful techniques for mineral analysis.

\section{ACKNOWLEDGEMENTS}

The authors wish to thank the management of Cape Peninsular University of Technology, Cape Town, South Africa for URF grant 2011/2012 offered H.K. Okoro for his doctoral research studies. The authors also acknowledge University of Ilorin, Ilorin, Nigeria for supplementation staff development award. Acknowledgement also goes to Mr Sebastian Brown, Alistair Aldonis and Ashley Davids of CSIR, South Africa for being part of the sampling team.

\section{REFERENCES}

1. Mattesson, A.; Herron, M.M. Paper 9308 presented at the Society of Core Analysis Annual Meeting, 1993, August 9-11, p 15. 
2. Wang, Z.; Chen, Z.; Tao, J. J. Coastal Res. 2006, 22, 683.

3. Fleeger, J.W.; Carmana, K.R.; Nisbetb, R.M. Sci. Total Environ. 2003, 317, 207.

4. Klavin, M.; Briede, A.; Rodinov, V.; Kokorite, I.; Parele, E.; Klavina, I. Sci. Total Environ. 2000, 262, 175.

5. Grabowski, L.A.; Houpis, J.L.J.; Woods, W.I.; Johnson, K.A. Chemosphere 2001, 45, 643.

6. Adamiec, E.L.; Helios-Rybicka, E. Polish J. Environ. Studies 2002, 11, 669.

7. Binning, K.; Baird, D. Water SA 2001, 27, 461.

8. Fatoki, O.S.; Awofolu, R.O. J. Chromatogr. 2003, 98, 225.

9. Botes, P.J.; Van Staden, J.F. Water SA 2005, 31, 183.

10. Okonkwo, J.O.; Mothiba, M. South Africa J. Hydrology 2005, 308, 122.

11. Shuping, L.S.; Snyman, R.G.; Odendaal, J.P.; Ndakidemi, P.A. Water Air Soil Pollut. 2011, 216, 319.

12. Fatoki, O.S.; Okoro, H.K.; Adekola, F.A.; Ximba, B.J.; Synman, R.G. The Environmentalist 2012, 32, 48.

13. Rengel, Z. in Heavy Metal Stress in Plants from Biomolecules to Ecosystems, 3rd ed., Prasad, M.N.V. (Ed.), Springer Verlag: Berlin; 2004.

14. Zhang, X.B.; Liu, P.; Yang. Y.S.; Xu, G.D. Bot. Stu. 2007, 48, 435.

15. Kovac, I.; Hugh, S.C.; Neill, O.; Hermann. J.; Hauri, E.H. American Mineralogists 2010, 95, 292.

16. Kovac, N.; Faganeli, J.; Bajt, O.; Boris, V.; Angela, S. RMZ. Mater. Geoenviron. 2005, 52, 81.

17. Adekola, F.A.; Eletta, O.A.A. Environ. Monit. Assess. 2007, 125, 157.

18. Boily, J.F.; Gassman, P.L.; Peretyazhko, T.; Szanyi, J.; Zachara, M.J. Environ. Sci. Technol. 2010, 44, 1185.

19. Ravisankar, R.; Senthikumar, G.; Kiruba, S.; Chandrasekaran, A.J.; Prince, P. India J. Sci. Technol. 2010, 3, 774.

20. USEPA Method 3050B, Acid Digestion of Sediments, Sludge, and Soils. Revision 2, USEPA: New York; 1996.

21. Fang, G.C.; Wu, Y.S.; Chang, S.Y. Atmospheric Res. 2006, 81, 320.

22. Okoro, H.K.; Fatoki, O.S. Adekola, F.A.; Ximba, B.J.; Synman, R.G. Arabian J. Chem. 2013, http://dx.doi.org/10.1016/j.arabjc.2013.05.014. Aricle in press.

23. Muller, G. Geol. J. 1969, 2, 108.

24. Hiavay, J.; Jonas, K.; Elek, S.; Inczedy, J. Clay Minerals 1978, 26, 139.

25. Coates, J.P. The IR analysis of Quartz and Asbestos, Nelioth Offset Ltd.: Chesham, England; 1977.

26. Wenshi, L.G.B. J. Acta Mineralog. Sinica 1983, 1, 1.

27. White, J.L. Soil. Sci. 1971, 112, 22.

28. Russell, J.D. Infrared Methods, A Hand Book of Determinative Methods in Clay Mineralogy, Wilson, M.J. (Ed.), Blackie and Son Ltd.: New York; 1987; pp 11-67.

29. Summer, M.E. Handbook of Soil Science, University of Geogia, Boca Raton Hondor Press: New York; 1995.

30. Manoharan, S.S.; Kumari, N.R.S.; Patil, K.C. J. Mater. Res. Bull. 1990, 25, 731.

31. Dun, J.G.; Gong, W.; Shi, D. J. Thermochim. Acta 1992, 208, 293. 